\title{
Az integrált ellátás koncepcionális keretrendszere és az integráció lehetőségei az alapellátásban
}

\author{
Dózsa Csaba dr. ${ }^{1}$ - Borbás Fanni ${ }^{2}$ \\ ${ }^{1}$ Miskolci Egyetem, Egészségügyi Kar, Miskolc \\ ${ }^{2}$ Állami Egészségügyi Ellátó Központ, Budapest
}

\begin{abstract}
Mára már több ország egészségügyi kormányzata felismerte, hogy a krónikus betegségek kezelése, komplex rehabilitációs és prevenciós ellátások biztosítása újfajta szemléletet igényel. A tanulmány célja bemutatni, hogy az egészségügyi szektorban fellelhető és azon kívüli szolgáltatások integrációjára milyen módon van lehetőség; az alapellátás esetében a szolgáltatások integrációja hogyan valósul meg; valamint a szervezetek különböző szintű integrációja hogyan alakítja át az ellátások szervezését. A téma bemutatása érdekében a szerzók áttekintik a legújabb nemzetközi szakirodalmat, valamint a 2014. szeptember 1-2-án Barcelonában megrendezésre került V. Európai Alapellátási Fórum tapasztalatait. Az integrált ellátás átfogó szemlélete, illetve a helyi közösségek igényeihez való alkalmazkodás ösztönzőleg hat az új szervezeti, szolgáltatási formák kialakítására az alapellátásban. Az integrált szolgáltatási formák alkalmasak a betegek és a közösség igényeihez jobban alkalmazkodó, széles körú ellátások biztosítására, de minden esetben kiemelten fontos a céloknak megfelelő integrációdimenziók megválasztása.
\end{abstract}

Orv. Hetil., 2015, 156(22), 881-887.

Kulcsszavak: integrált ellátás, koordinált ellátás, egészségügyi alapellátás

\section{Conceptual framework of integrated care and options for integration in primary care}

Nowadays, several countries' health governments have recognized that the complex treatment of chronic diseases, prevention and rehabilitation requires a new approach. This study presents the possible solution of integrated service delivery in health and other sectors. Furthermore, it shows how the integration of primary care services was implemented and how the integration of different levels of providers changes the organization of care. This study is based on an overview of the relevant international literature, as well as the 5th European Primary Care Forum. The comprehensive approach of integrated care and adaption of the needs of local communities encourage the development of new organizational forms and services in primary care. The integrated service forms are more suitable to satisfy the needs of patients and communities and provide wide range of services, but it is important to find the appropriate dimensions of integration which would fit our goals.

Keywords: integrated care, coordinated care, primary care

Dózsa, Cs., Borbás, F. [Conceptual framework of integrated care and options for integration in primary care]. Orv. Hetil., 2015, 156(22), 881-887.

(Beérkezett: 2015. február 23.; elfogadva: 2015. március 26.) 
Az integrált ellátási formák, más néven koordinált, átfogó korlátok (határok) nélküli ellátások a világon egyre elterjedtebbé válnak a közszolgáltatások területén, ezen belül különösen az egészségügyi és szociális szektorban. Az új szervezeti megoldások leggyakrabban alkalmazott két megközelítése: a kórházi kezelés igénybevételének szempontjából magas kockázatú betegek menedzselése, koordinációja és a rendszerszintû ellátások integrációja, amelyek igyekeznek választ adni a fragmentáltan működő ellátórendszer problémáira. A koordinált ellátás magában foglalja a magas kockázatú, társbetegségekkel küzdő és nagy költségigényű esetekre irányuló esetmenedzsmentet (case management) és a betegségmenedzsment-programokat (chronic disease management program) is. Az integráció vonatkozhat ellátási szintekre (például: alap- és szakellátás), de multidiszciplináris együttmúködésre is (egészségügyi, szociális és civil szektor) [1].

Célunk a tanulmányban annak bemutatása, hogy hogyan értelmezhető az integrált ellátás fogalma, koncepciója, illetve az alapellátás esetében a szolgáltatások integrációja hogyan valósul meg; valamint a szervezetek különböző szintű integrációja hogyan alakítja az ellátások szervezését, hozzáférhetőségét. Egy másik publikáció tárgya lehet az integrált ellátás gyakorlati alkalmazási lehetőségeinek néhány ország példáján keresztüli szemléltetése, különösen az alapellátás területén.

Miközben az egészségügyi ellátórendszer szolgáltatásainak komplexitása folyamatosan növekszik, az egészségügyi ellátás szintjei közötti információáramlás gyakran nem megfelelő az új ellátási igényeknek való kihívások kezelésére. Orosz Éva szerint: „Talán a legfontosabb, hogy a koordinációs tevékenységek formálisan nincsenek jelen egyes rendszerekben: esetenként nem tudni, mely egészségügyi szakember felelős a koordinációért, és a koordinációs tevékenységet ritkán finanszírozzák" [2]. Továbbá megoldatlan a kompetenciák megfelelő szabályozása az orvosok és egészségügyi diplomások, szakápoló személyzet között.

Kincses Gyula 2008-as elemzésében kiemeli, hogy a jelenlegi egészségügyi alapellátás egyik fó hiányossága a zártság, a komplexitás hiánya, a betegútszervezés nehézsége és egyenetlensége. A kitörési pontok között szerepel ugyanakkor a praxis alaptevékenységeinek újrafogalmazása, a szakmai és tevékenységi területek kibővítése a foglalkozás-egészségügy irányába, a krónikus betegségben szenvedő betegkörök szakgondozása. Előbbi problémákra nemzetközileg is az integrált vagy összevont csoportközösségi praxisok kialakítását javasolják [3].

\section{Az integrált ellátás értelmezhetősége, koncepciója}

A WHO definíciója szerint az integrált ellátások rendszere összefogja az erőforrásokat, inputokat, vezetési és szervezeti megoldásokat, amelyek a diagnózis, kezelés, gondozás, rehabilitáció és egészségmegőrzés tevékenységeivel kapcsolatosak. Az integráció lényege, hogy fej- lessze a szolgáltatásokat a hozzáférés, a minőség, a betegelégedettség és a hatékonyság vonatkozásában [4]. Azonban magának az integrációnak a módszerei, alkalmazási területei egészségügyi rendszerenként igen eltérőek lehetnek. Éppen ezért az integrált ellátási modellek összehasonlítása komoly kihívás elé állítja a kutatókat, mivel a gyakorlatban ezek a modellek nem egy meghatározott séma alapján múködnek. Az egyes modellek integrációs dimenziói között nagy különbségeket találunk az integráció típusát, mélységét, mértékét, valamint a folyamatait tekintve [5].

Az integráció típusa alapján beszélhetünk funkcionális, szervezeti, szakmai és klinikai integrációról. A funkcionális integráció a fó támogatótevékenységek integrációját jelenti, mint a pénzügyi és HR-menedzsment vagy a stratégiai tervezés. Szervezeti integrációról különféle egyesülések, hálózatépítések kapcsán beszélhetünk. A szakmai integráció ennél már jóval speciálisabb szintet jelent, ami az egészségügyi szakembereknek stratégiai szövetségkötésre ad lehetőséget más intézményekkel, ellátókkal, míg a klinikai integráció a különböző ellátási folyamatok integrációját jelenti, mint például koordinált egészségügyi szolgáltatások nyújtása az igénybevevőknek. Ebben az esetben a fó cél, hogy a betegek az ellátást egy irányelvek által is szabályozott, egyetlen integrált folyamat keretében kapják meg. Ezek a típusok leírhatóak horizontális és vertikális szinten is. Előbbi az azonos szinten lévő szolgáltatók közötti szoros együttmúködést vagy akár szervezeti egybeolvadást is jelent (például a szociális-gyermekjóléti és egészségügyi alapellátásban), míg a vertikális integráció során különböző szintek közötti, főként az egészségügyi vagy szociális alap- és szakellátás szervezeteinek összekapcsolása következik be. Az integráció mértéke az autonómiától indulva terjedhet a teljes integráció felé, amelyben az integrált szervezet a felelős az ellátás folyamatosságának és az együttmúködési kereteknek a biztosításáért [5].

Megfontolásra érdemes az integráció témakörében az amerikai stratégiai menedzsment irodalmából származó példa (1. ábra), amely jól szemlélteti a vertikális és horizontális integrációkat az egészségügyi intézmények között [6]. Ez ugyan kórházi szempontból ábrázolja az

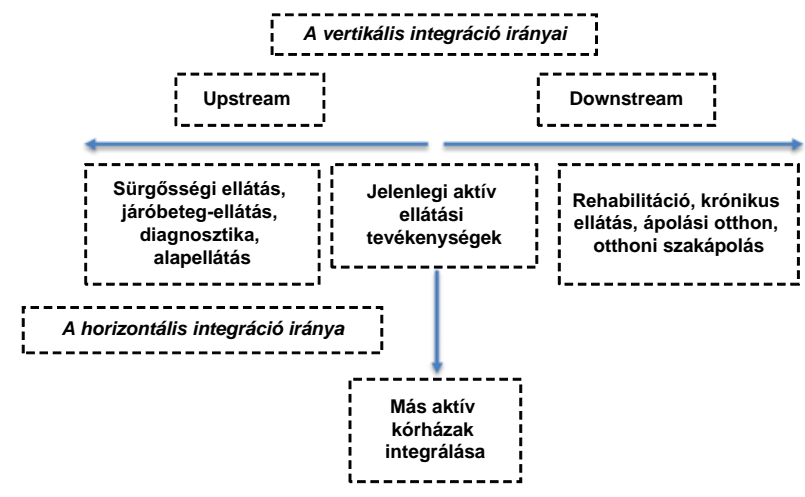

1. ábra $\quad$ Az egészségügyi szervezetek közötti vertikális és horizontális integráció lehetséges irányai [6] 


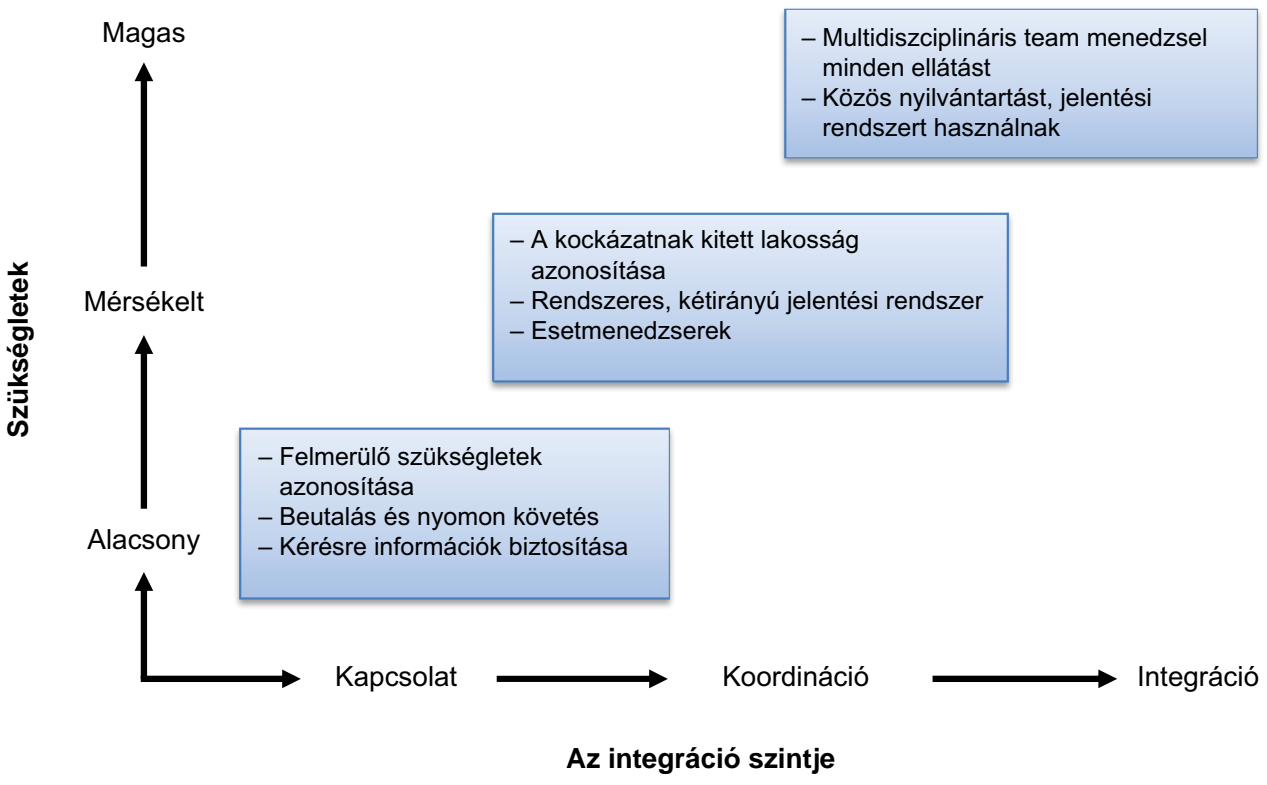

2. ábra

| Az integráció szintjei és a szükségletek összevetése Leutz keretrendszere alapján [7,8]

integrációs típusokat, de az ábrán az „upstream” integrációk között megemlítésre kerül az alapellátás is (háziorvosi praxisok), mint a kórház alapellátási kapujának integrálása a komplex szolgáltatóegységbe.

Leutz egy olyan keretrendszert készített, amelyben a szociális és egészségügyi ellátások háromszintü integrációjának lehetőségét írta le [7]. Az integráció szintjei szerint különbséget tesz kapcsolati típusú, koordinált vagy teljes integráció között. A kapcsolati típus esetében minden szervezet megőrzi a saját szolgáltatási struktúráját, múködési szabályait, finanszírozási és jogosultsági rendszereit, de együttmúködik más szervezetekkel. A koordinált változat ennél összetettebb, hiszen itt a különböző szektorokon átnyúló ellátások koordinációja érdekében új folyamatok és struktúrák alakulnak ki, valamint fontos szemponttá válik az információk rutinszerü áramlásának biztosítása is az érintett szereplők között. A teljes integráció esetében az integrált szervezet felelőssége az összes szolgáltatás, ellátás megszervezése, a pénzügyi és egyéb források biztosítása egy összevont menedzsment által irányított struktúra vagy különböző szervezetek között létrejövő szerződéses megállapodás keretében. Leutz ezeket a szinteket nem egymást kizáró rendszerben, hanem egymást kiegészítve képzelte el, vagyis az egyéni szükségletek befolyással vannak az ellátás során indokolt integráció szintjére $[7,8]$ (2. ábra).

Az integráció folyamatait tekintve beszélhetünk strukturális (szervezeti), kulturális és szociális integrációról. A strukturális integráció esetében a különböző feladatok, funkciók, tevékenységek és szakemberek összhangja valósul meg. A kulturális integrációnál már az értékek, normák, munkamódszerek és szimbólumrendszerek igazítása is megtörténik. A szociális integráció esetében pedig intenzívebbé válnak a szociális kapcsolatok a szerep- lők között, ezáltal pedig az integrációs célok, érdekek is erőteljesebben érvényesülnek $[8,9]$.

Schrijvers és Goodwin négy területet írt le, amelyben értelmezhető az integrált ellátás fogalma [10]:

- az egészségügyi és szociális ellátások integrációja,

- az alapellátás és a kórházi ellátás integrációja,

- egy területen belüli integráció (például mentális ellátások),

- a preventív és kuratív ellátások integrációja.

Összefoglalva tehát: az integrált ellátási kezdeményezések célja a (komplex) krónikus betegségek kimenetelének, illetve az ellátások töredezettségének javítása, valamint a különböző szervezetek közötti kapcsolatok kialakításával és/vagy ezen szervezetek szolgáltatásainak koordinációján keresztül az ellátási kontinuum biztosítása $[5,9]$. A fejlett ellátáskoordináció és kapuőri szerep csökkentheti a magas költségú ellátások iránti igényt a betegek „távol tartásával” a költséges fekvőbeteg-szakellátástól $[2,11]$.

\section{Az alapellátás fejlesztésének irányai, integrációs lehetőségek}

Az idejétmúlt alapellátási struktúra számos országban okoz gondot a lakosság széles körü igényeinek, valamint az alapvetően egy-egy elkülönült orvosi praxisra alapuló egészségügyi alapellátás humánerőforrás-igényeinek kielégítésében. Kincses megfogalmazásában: „A háziorvos ma jellemzően egy egyorvosos praxist jelent, amely általános »alap«-ellátást nyújt, és szervezi a hozzá forduló/ őt választó betegek ellátását. Múködési formája a praxis, amelynek vezetője a háziorvosi szakvizsgával rendelkező általános orvos" [3]. A rendszer új alapokra helyezése, 


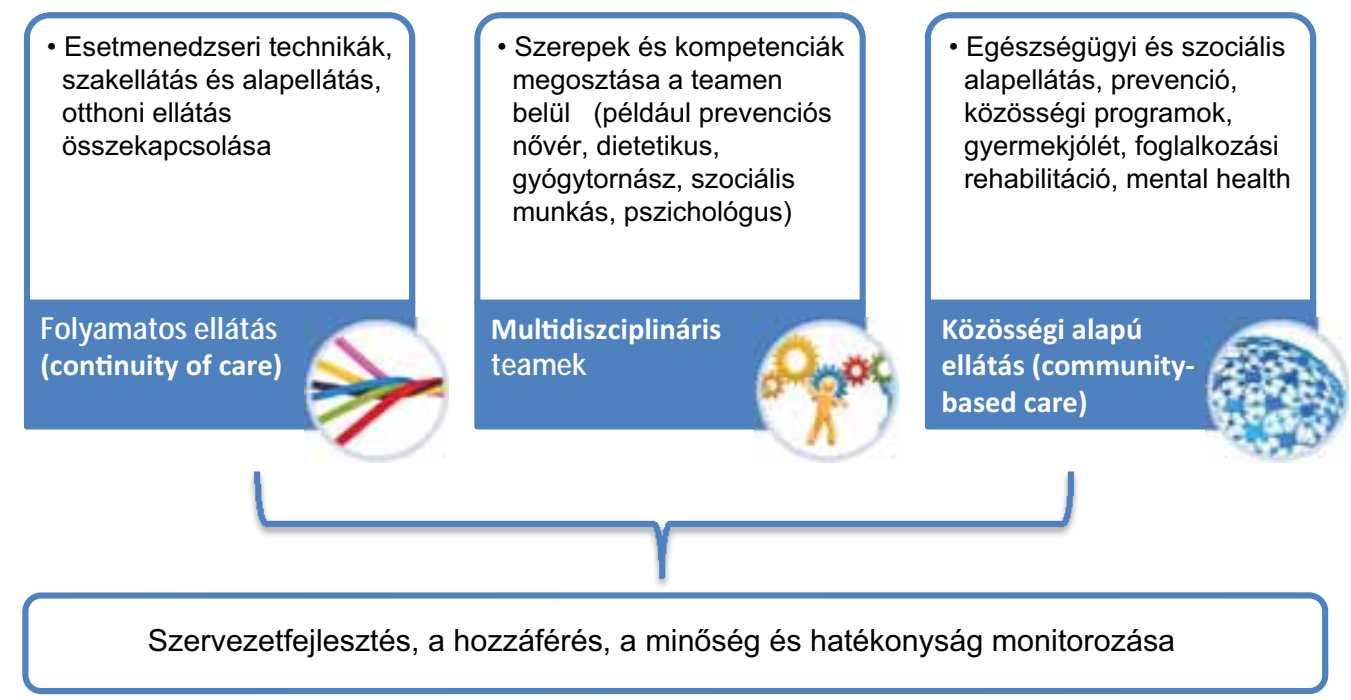

3. ábra

| Az alapellátás fejlesztésének meghatározó hívószavai Európában a 2014-es Európai Alapellátási Fórum tapasztalatai alapján

feladatkörének és személyi állományának újraértelmezése mára már halaszthatatlanná vált.

Biró a doktori értekezésében - az integrált ellátási modellek számára is fontos témaként - a háziorvosi ellátás tevékenységi körének tisztázatlanságában látja az egyik fő problémát, amely az alapellátás és a szakellátás közötti kompetenciák szintenkénti meghatározásának szabályozatlanságát jelenti. További problémaként emeli ki, hogy keverednek az adminisztratív, diagnosztikai és a terápiásgondozási célú tevékenységek, számos esetben az adminisztratív feladatok túlterhelik a praxisokat [12].

\section{Hivószavak az egészségügyi alapellátás fejlesztésében}

A Barcelonában 2014. szeptember 1-2-án tartott Európai Alapellátási Fórum témakörei, elhangzott előadásai és poszterei alapján készült a 3. ábra, amely azokat a legfontosabb hívószavakat mutatja be, amelyek jelenleg legjobban jellemzik az egészségügyi alapellátás fejlődésének irányát [13]. Az előzőekben kiemelt integrált ellátási modell és a folyamatos ellátás koncepciója szintén beleilleszkedik az európai trendekbe, és jelentős részben az egészségügyi és szociális alapellátás fejlődésének is a kulcsfogalmai és irányai közé tartoznak.

Mind a három témakör lényege, hogy az alapellátás hatékonyságának és ütőképességének növeléséhez elengedhetetlen az alapellátás határainak bővítése vagy lebontása. A modern egészségügyi alapellátásnak a közösségi ellátások között van a helye, más szóval a közösségi alapú ellátás/szolgáltatás (community-based care) biztosít megfelelő környezetet a kibővülő funkciókkal működő, fejlődő alapellátási integrált szolgáltatóknak, praxisközösségeknek. Kulcsfogalom ezen a téren a közösségben tartás, amely főként az egyedül élő idősek vagy a sok nehézséggel küzdő, hátrányos helyzetű vagy fogyatékos gyermeket nevelő családok számára biztosít programokat és lelki támaszt. További hívószavak a horizontális integráció vagy legalábbis a közösségeknek végzett - több ellátási szektoron átívelő - alapellátási feladatok szoros összekapcsolása [13].

A szolgáltatások zömét multidiszciplináris teamekben végzik gondozási terv, egyéni egészségterv alapján. A terápia alapját képező diagnózis felállítása továbbra is orvosi kompetenciában történik, de a terápiás terv megvalósításában és a speciális szolgáltatások elvégzésében, mint a dietetikai tanácsadás, a fizioterápia, gyógytorna, pszichológiai konzultáció, már az újonnan bevont szakemberek munkája a meghatározó [13].

Az egészségügyi szolgáltatások nyújtásában elengedhetetlen a betegek ügyfélként való kezelése, és ennek megfelelően az esetmenedzseri technikák alkalmazása, az alap- és szakellátás rendszerének szoros összekapcsolása a folyamatos ellátás (continuity of care) gyakorlatának megvalósítása révén. A szakellátással való napi szintű kapcsolatokat a kiterjedt infokommunikációs rendszerek biztosítják, az előjegyzések, betegútkövetés, visszacsatolások megosztható adatbázisokba rendezésével, webes és mobiltechnológiák támogatásával. A komplikáltabb eseteknél az esetmenedzseri (case manager) technikákat alkalmazzák [13].

$\mathrm{Az}$ ellátások-szolgáltatások nyújtásának hátterében ennek megfelelően ki kell emelnünk a szervezetfejlesztést, az integrált informatikai rendszert és a monitoringot. A monitoring kiterjed az ellátások igénybevételére, mozgósító hatására, a betegelégedettség mérésére, az egyes ellátások, szolgáltatások minőségének, eredményességének és hatékonyságának vizsgálatára [13].

\section{Alapellátási funkciók és szakmai kapcsolatrendszerek}

A konferencia szekciói sora vették az egyes ellátási-szolgáltatási elemek helyzetét és fejlődését, újdonságait, 


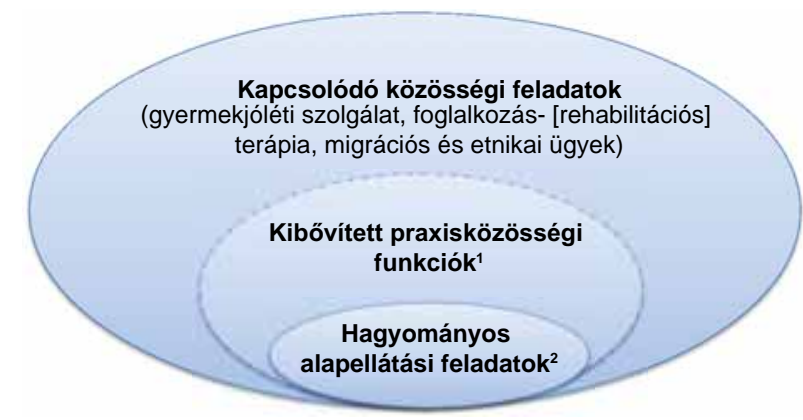

4. ábra

\begin{abstract}
Egymásra épülő ellátási és szolgáltatási körök az alapellátásban ${ }^{1}$ Kibővített praxisközösségi modell: dietetika, pszichológia gyógytorna, prevenciós nővér, állapotfelmérés és aktív prime és szekunder prevenció, szociális munka. További kérdés az otthoni ellátások körének bővítése és szervezése. A mostani otthoni szakápoló-szolgálatok intenzívebb bevonásával történjen, vagy kötelező elemként kellene megszerveznie minden praxisközösségnek.

${ }^{2}$ Hagyományos alapellátási feladatok a magyar egészségügyben: háziorvosi és házi gyermekorvosi ellátás, védőnői ellátás, iskola-egészségügyi ellátás, ügyeleti ellátás
\end{abstract}

fejleményeit az EU-s országokban. Külön-külön szekciókban részletesen vizsgálták például a teamek egyes tagjainak, mint például a dietetikusoknak, gyógytornászoknak, prevenciós munkatársaknak, pszichológusoknak a képzettségét, szerepét, további szerepvállalásuk lehetőségeit, helyzetüket, valamint az utánpótlásuk kérdéseit. Megkülönböztethetjük a hagyományos alapellátási résztvevőket: családorvosok, fogorvosok, praxisnővérek, akiknek a munkáján alapul a kibővített modell (4. ábra) [13].

Az Európában futó programok - számos helyi, alulról jövő kezdeményezés eredményeként - többnyire regionális, tartományi szinten valósulnak meg (például Toscana, Katalónia) és nem országos szintűek. Az észak-, nyugat- és dél-európai egészségügyi rendszerek túlnyomó részben decentralizáltan múködnek, amelyben egyegy régió, tartomány, nagyváros önállóan szervezi helyi egészségügyi rendszerét, ezzel tág teret biztosítva a színes és sokrétű szervezeti megoldásoknak, a horizontális kapcsolatok kiépítésének más közösségi alapú ellátásokkal. Ebból a szempontból a Kelet-Európában, a szocializmus idején kialakult hierarchikus és centralizált (akár egészségügyi, akár szociális) ellátórendszerek és ellátásszervezés általánosságban nem biztosít kellően támogató környezetet a fentiekben felvázolt - horizontális irányban - rugalmasan múködő integrált ellátási formák kialakítása számára [13].

\section{Változások az alapellátás szervezeti müködési kereteiben}

Mindezek következtében az alapellátásban is figyelemre méltó változások történtek az elmúlt időszakban. A helyi közösségek igényeihez való alkalmazkodás ösztönzi az új szervezeti, szolgáltatási formák kialakítását az alapellátásban, amelyek közül a The King's Fund az alábbi négy modellt emeli ki [14].

\section{Alapellátási hálózatok/szövetségek}

Egyfajta háziorvosi szövetség, amelynek célja, hogy megossza a felelősséget olyan különböző funkciók felett, mint oktatás és képzés, szolgáltatások nyújtása és vásárlása, adminisztratív funkciók stb. Ezek a szövetségek elsősorban a szolgáltatások fejlesztése céljából jönnek létre és biztosítják, valamint koordinálják a közösségi szükségleteken alapuló, egyénközpontú szolgáltatásokat, továbbá javítják a szolgáltatásokhoz való földrajzi hozzáférhetőséget. A szövetségek szervezeti formája eltérő lehet, de nagyon jól ki tudták használni az együttműködésben rejlő előnyöket, valamint javítani tudták a klinikai szolgáltatások menedzselését. A pénzügyi ösztönzők, valamint a kollektív elkötelezettség érzése együttesen erősíti a célok elérését, a közösségi terveken alapuló közös munkát, illetve segíti az új, kibővített ellátási formák biztosítását a krónikus betegek részére. Emellett fontos szerepet játszik a közös informatikai platform létrehozása a szövetség tagjai között. Ilyen szövetségre példa az angliai Tower Hamlets vagy a Zorg In Ontwikkeling (ZIO) Network Maastrichtban. A ZIO nonprofit szervezetként múködik 2006 óta. Összesen 170 ezer regisztrált beteg ellátásáról gondoskodik. A hálózatban 90 háziorvos, 52 ápoló, 150 gyógytornász és 30 dietetikus dolgozik. A ZIO létrehozását a krónikus betegségek megnövekedett aránya, valamint ebből adódóan a kórházi felvételek magas száma indokolta. Egy Hollandiában végzett kutatás azonban kimutatta, hogy a krónikus esetek meglehetősen nagy százalékának ellátásához nincs szükség kórházi infrastruktúrára, mivel az ellátások jelentős hányada a betegek otthonában is megoldható. A szervezet, az integrált szolgáltatások nyújtása mellett, folyamatos képzést és infokommunikációs támogatást biztosít a személyzet számára, és felelős a szolgáltatások minőségének biztosításáért mind a helyi szintű, mind a helyszínre küldött munkatársak esetében [13]. A ZIO hálózatában mind a horizontális, mind a vertikális integrációt megtaláljuk. A modell bevezetése óta a kórházak 40\%-a múködik együtt háziorvosokkal és körülbelül egynegyedük ápolási otthonokkal. Bár az integrált modell szereplői között a kapcsolat jóval erősebb az együttmúködésnél, hiszen az alapvető szolgáltatási folyamatok, betegutak szabályozására is nagy hangsúlyt fektettek [15].

\section{Szuperpartnerségek}

A szuperpartnerség egy több telephelyen létrejövő, egyetlen, nagyméretű, háziorvosi partnerségi fúzió. Angliában a szuperpartnerségek vezető trendet jelentenek az alapellátási rendszerek fejlődési irányában, hiszen akár 50 ezer beteg ellátására is alkalmas 1-1 ilyen partnerség. A szuperpartnerségek célja, hogy olyan életképes ellátási alternatívát biztosítsanak a lakosság számára, amelynek igénybevételével megelőzhetők lesznek a kórházi felvételek, emellett javítják az ellátás minőségét, jobb karrierlehetőséget biztosítanak az orvosoknak és szakdolgozóknak, valamint optimális szervezeti méretgazdálkodást 
tesznek lehetővé. Szuperpartnerségre példa az angliai The Vitality Partnership, amely háziorvosi ellátásokat, járóbeteg-ellátást, diagnosztikai ellátást is biztosít [14, 16].

\section{Regionális és nemzeti multipraxis-szervezetek}

A helyi közösségekben múködő praxisközösségektől és a szuperpartnerségektől eltérően ezek a multipraxisok regionális szintű partnerségi szerveződések, ahol központosított szinten múködnek a back office és a menedzseri feladatok. Ezekben a szervezetekben a klinikai és menedzsmentfolyamatok standardizálásával kívánják javítani a helyi szintű forrásfelhasználást. Ennek érdekében pedig központi monitoringrendszert dolgoztak ki [14]. Ilyen típusú szervezet az angliai The Hurley Group, amely 17 háziorvosi praxis partnersége.

\section{Közösségi egészségügyi szervezetek}

A szervezetek praxishálózatokból állnak, amelyek gyakran egy épületen belül helyezkednek el. A szervezetek kombinálják a betegközpontúságot erős közösségorientáltsággal, valamint jelentős állami és közösségi részvétel mellett gyakorolják a tulajdonosi jogokat is. Ezekben a szervezetekben a közösség széles körú bevonásával a népesség egészségének javítása érdekében az alapellátás keretében nyújtott szolgáltatások szélesítése, elérhetőbbé tétele a cél. Tevékenységeit az egészségügyi és szociális szükségletek határozzák meg, ezekre alapozza az ellátások és a közösség fejlesztését is. Ezeket a szervezeteket elsősorban az elmaradott, hátrányos helyzetú, illetve távol eső településeken alkalmazzák, ahol korlátozott az ellátásokhoz való hozzáférés. Ebből adódóan a szervezetek holisztikus szemléletben dolgoznak, hiszen ezeken a területeken az ellátások szervezésénél kiemelkedően fontos az alkalmazkodás a közösség komplex szükségleteihez, hogy eredményesen lehessen kezelni például a szegénység vagy a hajléktalanság okán felmerülő szükségleteket. Erre a modellre példa a londoni Bromley by Bow Health Center, amely a hátrányos helyzetû városi lakosság számára nyújt ellátásokat. A multidiszciplináris alapellátási team 6000 betegnek - akik közel 70 különböző országból származnak - kínál szolgáltatásokat, amelyek a gyógyítóellátásokon túl a megelőzésre, palliatív ellátásra, rehabilitációra, valamint egészségfejlesztésre is kiterjednek. A szolgáltatásnyújtásnál a hozzáférhetőség kiemelt szempont, ezért sem földrajzi, sem finanszírozási, sem kulturális korlátot nem találunk. A központ egy integrált ellátórendszer keretében szerződésben áll szakorvosokkal, gyógytornászokkal, pszichológusokkal, hospice- és szociális ellátókkal. Ezek a szereplők a helyi szervezetek képviselőivel kiegészülve (iskolák, rendőrség stb.) együttesen vesznek részt a közösséget érintő elemzések felállításában, amelyek a továbbiakban a közösségorientált alapellátási stratégia alapját jelentik majd [14].

\section{Ajánlások, következtetések}

A konferencia felvetései és a nemzetközi tapasztalatok azt mutatják, hogy a különböző szintű és típusú szolgáltatások integrációja az ellátás fragmentáltságának csökkentése, belső határainak lebontása révén kiváló eszköz lehet főként a krónikus betegségek kezelésére, részben a komplex rehabilitációs vagy egészségmegőrző-preventív szolgáltatások nyújtására, akár egészségügyi szektoron belüli, akár szektorok közötti ellátások esetében is. Az integrált ellátás előnye, hogy rugalmasabban igazítható a betegek, ügyfelek és a közösség szükségleteihez. A jól megválasztott integrációs forma pedig nagyban segítheti az ellátások hatékonyabb szervezését, az információk áramlását, valamint javíthatja a betegek komfortérzetét és elégedettségét is. Az ellátások integrációja előtt érdemes minden esetben felmérni a közösségi (lakossági) szükségleteket, illetve megvizsgálni, hogy milyen ellátási formák integrációja vezetne a legnagyobb eredményre. Részben ez fogja meghatározni azt is, hogy milyen szintű, irányultságú és mélységü integrációt érdemes megvalósítani és milyen lépésekben.

A nemzetközi példák azt is igazolják, hogy egy rendszeren belül akár vertikális és horizontális szintú integráció egyidejü kialakítása is lehetséges, illetve hogy az egyes szervezetek között az egyszerú együttmúködéstől kezdve, a szabályozott ellátási utak, az irányítás, gazdálkodás, ellenőrzés és minőségbiztosítási rendszerek közös múködtetése is kivitelezhető. Az integrált szolgáltatási hálózat akkor múködhet hatékonyan, ha különböző típusú szolgáltatók szolgáltatásainak összhangját valósítja meg vagy azonos profilú szervezetek együttmúködése magasabb szintü, illetve komplexebb ellátást tud biztosítani az igénybevevók számára. Ahhoz, hogy a szervezetek pontosan tudják, hogy a rendszerben milyen szolgáltatásokat kell nyújtaniuk, ahhoz szabályozni szükséges az elvárt kompetenciákat, támogatni kell a megfelelő képzési és információs hálózatok kiépítését, valamint a tapasztalatcserét a szereplők között.

Véleményünk szerint hazánkban is indokolt lenne az integrált ellátási formák rendszerének kidolgozása, melynek megvalósítására akár több modellszintú pilot program indulhatna. Léteznek jó kezdeményezések, de ezek többnyire ki is merülnek a szolgáltató szervezetek közötti együttmúködésben. Hiányoznak a közös célok, érdekek, információs és kommunikációs hálózatok, de nincsenek megfelelő finanszírozási ösztönzők sem.

Addig, amíg a szolgáltatók a saját fenntarthatóságuknak biztosítását tartják szem előtt és nem az igénybevevők valós szükségleteinek megfelelő szintű kielégítését és a megelőzés fontosságát, addig az integrált ellátások sem hozzák majd a velük szemben támasztott követelményeket, mivel ezek a modellek akkor múködhetnek igazán eredményesen, ha egy alapvető szemléletváltással is társulnak, miszerint az egyén a szükségletei és igényei révén aktív résztvevője és formálója az ellátásnak. 
Anyagi támogatás: A közlemény megírása anyagi támogatásban nem részesült.

Szerzői munkamegosztás: D. Cs.: Szakirodalom áttekintése, nemzetközi gyakorlatok tanulmányozása, V. Európai Alapellátási Fórum tapasztalatainak összegzése, ábrák készítése, kézirat megszövegezése, ajánlások megfogalmazása. B. F.: Szakirodalom áttekintése, nemzetközi gyakorlatok tanulmányozása, kézirat megszövegezése, szerkesztése, ajánlások megfogalmazása. A cikk végleges változatát a szerzők elolvasták és jóváhagyták.

\section{Érdekeltségek: A szerzőknek nincsenek érdekeltségeik}

\section{Köszönetnyilvánítás}

A szerzők köszönik $D r$. Németh Évának a cikk szerkesztésében nyújtott segítségét.

\section{Irodalom}

[1] Singh, D.: Transforming chronic care, Evidence about improving care for people with long-term conditions. The University of Birmingham, 2005. http://www.download.bham.ac.uk/hsmc/ pdf/transforming_chronic_care.pdf

[2] Orosz, É.: Health politics reader. Electronic edition. [Egészségpolitikai szöveggyújtemény. Elektronikus kiadvány.] Cambridge University Press, ELTE TÁTK, Budapest, 2011. [Hungarian]

[3] Kincses, Gy.: Reform of primary care - 2008. [Alapellátási reform - 2008.] http://www.kincsesgyula.hu/dokumentumok/egeszseghaz $\% 20$ koncepcio.pdf. [Hungarian]

[4] Integrated health services - what and why? WHO Technical Brief No. 1, 2008. http://www.who.int/healthsystems/service_ delivery_techbriefl.pdf

[5] Nolte, W., Pitchforth, E.: What is the evidence on the economic impacts of integrated care? Policy Summary 11. WHO Regional Office for Europe and European Observatory on Health Systems and Policies, 2014. http://www.euro.who.int/_data/assets/ pdf_file/0019/251434/What-is-the-evidence-on-the-economicimpacts-of-integrated-care.pdf
[6] Swayne, L., Duncan, W. J., Ginter, P.: Strategic Management of Health Care Organizations. 5th edition. Blackwell Publishers, Cambridge, 2006.

[7] Leutz, W.: Five laws for integrating medical and social services: lessons from the United States and the United Kingdom. Milbank Q., 1999, 77(1), 77-110.

[8] Nolte, E., McKee, M.: Integration and chronic care: a review. In: Nolte, E., McKee, M. (eds.): Caring for people with chronic conditions: A health system perspective. Open University Press, Maidenhead, 2008.

[9] National Evaluation of the Department of Health's Integrated Care Pilots. RAND Europe, Ernst \& Young LLP, 2012.

[10] Schrijvers, G., Goodwin, N.: Looking back whilst moving forward: observations on the science and application of integrated care over the past 10 years and predictions for what the next 10 years may hold. Int. J. Integr. Care, 2010, 10, e057.

[11] Hofmarcher, M., Oxley, H., Rusticelli, E.: Improved health system performance through better care co-ordination. Working Papers. OECD Publishing, Paris, 2007.

[12] Biró, K. Kalasné: Challanges of the Hungarian health care system. Doctoral dissertation. [A magyar egészségügyi ellátórendszer kihívásai. Doktori értekezés.] Debreceni Egyetem, Debrecen, 2011. [Hungarian]

[13] EFPC 2014 Bi-annual conference: The Future of Primary Health Care in Europe V, 1/2 Sept Barcelona. http://www.euprimarycare. org/barcelona/efpc-2014-bi-annual-conference-future-primaryhealth-care-europe-v-12-sept-barcelona

[14] Smith, J., Holder, H., Edwards, N. et al.: Securing the future of general practice: new models of primary care, The King's Fund and Nuffield Trust, 2013. http://www.nuffieldtrust.org.uk/ sites/files/nuffield/130718_full_amended_report_securing_ the_future_of_general_practice.pdf

[15] KPMG healthy care: Integrated care towards new coalitions in healthcare, 2014. http://www.zio.nl/workspace/uploads/Nieuws/ integrated-care_english-53e8bba8216a9.pdf

[16] https://www.vitalitypartnership.nhs.uk/

(Dózsa Csaba dr., Verốce, Meredek u. 2., 2621 e-mail: csaba.dozsa@invitel.hu) 